\title{
Cross Institutional Study of the Causes of Absenteeism among University Students in Barbados and Nigeria
}

\author{
Grace A. Fayombo (Corresponding author) \\ School of Education, Faculty of Humanities and Education \\ The University of the West Indies \\ Cave Hill Campus, Barbados
}

Tel: 1246-257-3998Ｅ-mail: grace.fayombo@cavehill.uwi.edu

Babalola J. Ogunkola

School of Education, Faculty of Humanities and Education

The University of the West Indies

Cave Hill Campus, Barbados

Tel: 1246-244-6776 E-mail: babalola.ogunkola@cavehill.uwi.edu

Yemisi L. Olaleye

Department of Social Work, University of Ibadan

Ibadan, Oyo State, Nigeria

Tel: 234-805-975-9846Ｅ-mail: yemisi1957@yahoo.co.uk

Received: January 13, 2012

doi:10.5539/jedp.v2n1p122
Accepted: March 15, $2012 \quad$ Published: May 1, 2012

URL: http://dx.doi.org/10.5539/jedp.v2n1p122

\begin{abstract}
This cross-institutional study investigated the student-centred, home, school and society related causes of absenteeism among 1000 undergraduate students from two public universities, 500 each from The University of the West Indies, (UWI), Cave Hill Campus, Barbados and The University of Ibadan (UI), Oyo State, Nigeria. Results revealed that the students were absent from lectures for student-centred, home, school and society related reasons and there were significant differences between UWI and UI students' reasons with school causes being the key factors for absenteeism among the students from both institutions. Additionally, gender differences were found among the Nigerian undergraduates' student-centred and school causes of absenteeism while gender did not affect the causes of absenteeism among the undergraduates in Barbados. These results were discussed with the hope of understanding and tackling absenteeism among the students from the two different institutions.
\end{abstract}

Keywords: Absenteeism, UWI, UI, Student-centred, Home, School, Society causes

\section{Introduction}

Absenteeism from lectures by the university students appears to be a serious problem that seems to transcend and defile all the strategies by the university authorities and lecturers' efforts to curb it. Investigators reported the magnitude of this phenomenon (Gump 2006; Hughes 2005; Hunter \& Tetley 1999; Longhurst 1999; McCarey, Barr \& Rattray, 2006; Nicholl \& Timmins 2005; Sharma, Mendez, \& O’Byrne 2005) and its consequences on the students' immediate academic achievement and future application of skills (Epstein \& Sheldon, 2002; Sade \& Stroud 1982). Since students are active participants in their learning experiences and must take responsibility for achieving their potentials through successful completion of each stage of their studies, it is common therefore to see many universities coming up with various measures to ensure students' attendance at lectures in accordance with their commitments to encourage and help the students to achieve their potentials to the maximum capability in their studies and in developing lifelong skills and competencies. Attendance is a key component in students' 
retention, progression, achievement and employability, it is therefore important that schools have in place effective mechanisms to monitor the attendance of students they consider to be "at risk", and to engage with them positively at an early stage (Heriot Watt University, Policy on Student Attendance, 2007).

Thus, in the Caribbean, The University of the West Indies, a three-campus entity, (Cave Hill, Barbados, Mona and St Augustine Campuses) has a common examination regulation which stipulates that: "Any candidate who has been absent from the university for a prolonged period during the teaching of a particular course for any reason other than illness ... may be debarred by the relevant Academic Board, on recommendation of the relevant Faculty Board, from taking any University examinations" (UWI Students’ Handbook, 2011 - 2012 p.11).

Similarly, in Nigeria, the University of Ibadan authority also makes it mandatory for students to attend $75 \%$ of the lectures before being allowed to sit for examinations (UI, Postgraduate Prospectus, $2010 \mathrm{pp} \mathrm{17-18).} \mathrm{Other}$ universities around the globe also formulated attendance policies to monitor their students' attendance at lectures. For instance, Heriot Watt University expects all the students to attend all scheduled learning sessions; timetabled lectures, seminars, tutorials, workshops and laboratory sessions. The University of Oxford suggests that students should sign a legally binding contract requiring them to attend lectures and tutorials, complete written work and attend practical lessons. The attendance policy of the University of New Brunswick also makes it mandatory for each student to attend all scheduled classes. Despite all these efforts, investigators still report that students skip classes due to no just reasons. The reasons for such persistent absenteeism from lectures are the main concern of the researchers in this study and whether the reasons for students' absenteeism will vary from one institution to another because of different locations. It is our expectation that the UWI and UI students will have different reasons for absenteeism from lectures because of the different locations.

\section{Causes of Absenteeism among Higher Education Students}

Researchers investigated why students do not attend classes and also why they do. Recently, Wadesango and Machingambi (2011) found that absenteeism is rampant among the students in three South African universities due to reasons like: lack of subject interest, poor teaching strategies by lecturers, unfavourable learning environment, too much socialization, part-time jobs to augment meagre bursaries granted by various sponsors and poor relations with the lecturers.

Dhaliwal (2003) also found among 101 medical students in Delhi, that illness, family commitment, teacher/topic, or lecture period spent in an extended clinical posting were causes of absenteeism and higher attendance was associated with better marks. In a similar study of medical students' attendance at lectures in the UK, Mattick, Crocker and Bligh (2007) reported that attendance dwindle as they progress in their academic career. They reported that more students $(87 \%)$ attended non-compulsory plenary lectures to understand factors affecting the value placed by students on the first two years of a contemporary medical curriculum at the beginning of the first academic year, with numbers decreasing to (78\%) as the year progressed. In an earlier study at the University of Canterbury, New Zealand, Hunter and Tetley (1999) interviewed 168 full-time students about not only their reasons for not attending lectures but also their reasons for attending and found that tertiary education students will not miss lectures that were interesting and those considered important to their degree, those in which there was a lot of materials given out, those where they liked the subject content or in which the lecturer was good, while those that they will not attend according to (Gump, 2006; Nicholl \& Timmins, 2005) also, were perceived as academy-centred such as: failure to connect the content of the lecture to assessment or the 'real world', the availability of lecture material in online forms, unexciting, unchallenging lecturers, timing of lectures and competing assignment commitments.

In spite of the serious consequences of lecture absenteeism as documented by Epstein and Sheldon (2002) and Moore, Armstrong, and Pearson (2008), literature still suggests that the reasons for poor attendance are not well researched nor easy to determine as it is a complex and sensitive issue (Hamilton, Hinton, \& Qian 2008) because an individual's decision to come to lectures or not will be influenced by many factors. Furthermore, it is often believed that a student who has poor attendance is poorly motivated, but this need not necessarily be the case. A measure of aggregate attendance such as an average or percentage of all weeks in the term is a rather crude measure and does not take into account the different emphases at different parts of the term, whether the scene setting at the beginning, the rhythm established during the term itself, the preparation weeks preceding in-term assessment, the systematic and continuous build up of the student's knowledge base over the term, or the preparation for a major end of term assessment such as an examination (Hamilton, Hinton, \& Qian 2008).

However, in the Caribbean, in the The University of the West Indies, especially in Barbados, literature abounds on improving the quality of teaching and learning, maximizing students' learning and knowledge creation through the open campus learning system, integration of information communication technology into the 
institution's programme of activities through the use of videos in the classroom and through blackboard and e-learning systems (Longsworth 2009; Watson \& Barbado 2008); the significance of the library in supporting teaching, learning and research (Helenese-Paul 2008) and supposed differences in learning styles (Burskey 2004), yet there is little focus on the issue of student absenteeism from lectures in spite of its frequency, its consequences and serious complaints by faculty on students' poor attendance at lectures during personal discussions and departmental meetings until recently that literature identifies the implications of absenteeism from lectures among undergraduate students in Barbados (Fayombo 2010) and evidences of students' absenteeism from elementary and primary schools in Jamaica (Knight \& Rapley, 2007).

Similarly, in Nigeria, investigators focused on various tricks adopted by students in perpetuating examination malpractices in tertiary institutions (Yakubu,1998); the efficacy of moral/religious counselling in curbing examination malpractices among the students (Eweniyi, 2002) and coping with challenges of realistic assessment in English in higher education (Ezema, 2001), attitudes of Nigerian lecturers and students towards sexual harassment (Fayombo, (2007); incidences of absenteeism among the primary and secondary school students (Ofovwe \& Ofili, 2007; Oghuvbu 2008) and causes of absenteeism and dropout among secondary school students in Delta State, yet little had been done in the area of research to find out the causes of absenteeism among the Nigerian university students in spite of its debilitating consequences on students' conduct during the examination, students' potentials, students' acquisition and application of skills in future endeavours. It is against this back drop that this research is conducted.

\section{Present Study}

This study is therefore carried out to investigate the causes of students' absenteeism from lectures among the UWI students in Barbados and the UI students in Nigeria and also to find out whether there will be statistically significant differences in the causes of absenteeism between UWI and UI students with the hope of proffering solutions to these problems. From the literature reviewed, it is evident that absenteeism from lectures and its attending consequences is a pandemic disease among university students around the globe, yet the reasons for poor attendance are not well researched among the university students in both institutions where this study was carried out despite the fact that The University of the West Indies, Barbados and the University of Ibadan, Nigeria are not immune to students' absenteeism from lectures. Additionally, this study is peculiar because there had not been any cross institutional study of the causes of absenteeism between UWI and UI students and even among university students around the globe as categorized in this study into: student-centred causes such as lack of interest in school work; home related causes like family commitments; school related causes like lecture methods, schedules, contents and society related causes such as transportation and inclement weather. This categorisation will enable the researchers to have a better focus on the category most responsible for students' absenteeism.

Howe (2000) posits "It will not be advisable to wait on statistics before tackling the problem and finding solutions to absenteeism, ... statistical trends by definition takes time to develop, unfortunately, by the time the data emerge, fully crunched, the crisis will also have emerged, fully blown". In UWI and UI, it has been observed that many students skip lectures and tutorial classes without genuine reasons, some of them will come to the class, sign the attendance register and leave before the lecture ends while some will not even attend a single lecture and they will see their lecturer for the first time on the examination day! This has grievous consequences on the students' academic achievement and future endeavours. It is of great necessity and urgency therefore to conduct this research to investigate the causes of absenteeism from lectures among the UWI and UI students and find out whether there will be statistically significant difference in the causes of absenteeism between UWI and UI students with the hope of proffering solutions to this problem. We expected that when compared, there will be differences in the students' reasons for absenteeism from lectures because of different personality makeup and cultural settings.

To this end therefore, this study addressed the following research questions:

1) What are the student-centred, home, school and society related causes of absenteeism among the university students in Barbados and Nigeria?

2) Which of the causes will be mostly responsible for absenteeism among the university students in UWI and UI?

3) Will there be statistically significant differences in the causes of absenteeism between UWI and UI students?

4) Will gender affect the causes of absenteeism among the UWI and UI students? 


\section{Method}

\subsection{Participants}

The participants were 500 UWI students with age ranging from 16 - 50 years; $(M=25.52, S D=8.12 ; 205$ males, 295 females) and 500 UI students with age range from $20-47$ years, $(M=30.91, S D=6.90 ; 211$ males and 289 females) 2010/2011 academic year. The UWI students were randomly selected from the faculties of Social Science, Humanities and Education, Law, Medical Sciences, Pure and Applied Science, while the UI sample was randomly selected from the departments of Social work, Educational Management, Adult Education, Teacher Education, Physical and Health Education.

\subsection{Measure}

Factors Influencing Absenteeism Questionnaire (FIAQ) developed by the researchers was the only instrument used for data collection in this study. It has two sections; Section A comprises of the demographic variables such as gender, faculty/department, year of study, age etc. Section B consists of 35 items designed to measure the causes of absenteeism among the university students with four subscales categorized as:

1) Student-centred sub scale consisting of ten items which are related to the students' personal factors like:

"Lack of interest in school subjects or courses",

"Courses not relevant to real world",

"Inability of the mental capacity of students to match the course or courses opted for",

"Preparation for examination",

2) Home related sub scale consists of seven family based factors such as:

"Over expectation of parents",

"Lack of parental care and involvement in their children's academic activities",

"Working to meet up the daily needs for the family",

"Poor family relationships".

3) School related subscale consists of ten items like:

"The poor teaching skills of lecturers leading to boring lectures",

"Lecturers not turning up for scheduled lectures",

"Excessive homework and project work for students",

"Clashes of courses on the time table".

4) Society related subscale consists of eight items including:

"Low societal value for education",

"Inclement weather",

"Transportation problems",

"Low level of job opportunities that match person's academic qualifications".

Thus the student centred scale consists of items 1-10; home causes scale consists of items $11-17$, School causes consists of items $18-27$ and finally, the society causes scale consists of items 28-35. All items were measured by a modified 4-point Likert scale response anchors ranging from strongly agree to strongly disagree with corresponding scores of $4,3,2$, and 1 . The 35 items were generated during the review of literature and the initial versions were given to experts for suggestions and comments before coming up with the final version. The reliability of the instrument was ascertained by carrying out pilot studies among the UWI and UI students. The instrument yielded Cronbach's Alpha reliability coefficients of .87 and .79 among the UWI and UI samples respectively. The validity was ascertained by the choice of items which were subjected to internal consistency analysis (Cronbach's Alpha), which is an index of item homogeneity and an indication of construct validity.

To further ensure the validity of the instrument, the data were also subjected to a principal component analysis with varimax rotation. The various indicators of factorability were good; the components can be thought of as representing the four categories of factors causing absenteeism among the students thus: Component 1: Student-centred causes; Component 2: Home causes; Component 3: School causes; Component 4: Society causes. The components and the variable that load on them are shown on Table 1. The four components together explained $40.6 \%$ of the variance in absenteeism. 
Insert Table 1 Here

\subsection{Procedure}

Informed consent of the students to participate in the survey was obtained during the lectures prior to the administration of the questionnaire. The students were briefed of the purpose of the research and that they were free not to participate in the study if they so wished but they all consented to participate. The students were surveyed in their lecture halls with the help of four research assistants who had been groomed in the administration of the instrument. The researchers took time to brief the participants on the process of answering the items in the questionnaire and that it is not for examination purpose but for research and they were also told that the information would remain confidential. To buttress this, the students were told not to write their names or identification numbers on the instrument. The researchers ensured that all the scales in the instrument were properly filled and the questionnaires were collected immediately the participants had finished. The administration of the instrument lasted for approximately 30 minutes.

\subsection{Data Analysis}

The data collected were entered into SPSS version 16, Descriptive Statistics, Independent t-test and ANOVA were conducted to analyse the data.

\section{Results}

The students were asked to indicate the number of times they were absent from the lectures during the semester. From the findings on table 2, it is evident that the problem of absenteeism was quite prevalent among the students in the two universities that participated in this study thus confirming the globalisation of absenteeism from lectures among the university students.

\section{Insert Table 2 Here}

In order to address the problem of absenteeism from lectures, this study sought to categorise the major factors that give rise to this problem. The findings of this study thus revolved around the following four categories: student-centred, home, school and society causes.

Research Question 1: What are the causes of absenteeism among the university students in Barbados and Nigeria? Research Question 2: Which of the causes will be mostly responsible for absenteeism among the UWI and UI students?

\section{Insert Table 3 Here}

The findings on table 3 as well as figure 1 revealed that students were absent from lectures because of student-centred, home, school and society related reasons. It is also evident that the mean score for school or academic reasons was the highest indicating that many students from UWI and UI were absent from lectures most of the time because of school or academic related reasons like "poor teaching skills of lecturers leading to boring lectures", "lecturers not turning up for scheduled lectures", followed by students' personal reasons like: "lack of interest in school subjects or courses", "inability of the mental capacity of students to match the course or courses opted for", followed by home related causes like "working to meet up the daily needs for the family", "poor family relationships" and lastly by society related causes such as "low societal value for education", "transportation problems". This result indicates that school related causes are most problematic among the UWI and UI students thus demanding more attention from all the stakeholders.

Additionally, as shown in table 3, the UI students had higher means in school $(\mathrm{M}=35.40)$ and home causes $(\mathrm{M}=$ 19.61) when compared with the UWI students $(M=30.01)$; $(M=17.74)$, while the UWI students had higher means in society related causes $(\mathrm{M}=17.60)$ when compared with their UI counterparts $(\mathrm{M}=15.49)$. Interestingly, the students from UWI and UI had almost the same means in the measure of student causes $(\mathrm{M}=29.14 ; \mathrm{M}=$ 29.37) respectively. This means that the UI students' reasons for absenteeism are more school and home based than their counterparts in UWI whose reasons for absenteeism are more resident in the society. The almost equal mean scores obtained in student-centred causes by UWI and UI students is an indication that the students' personal reasons for absenteeism from lectures are similar in spite of the different environments.

\section{Insert Figure 1 Here}

Having found the different causes of absenteeism among the students and the category that is most responsible for absenteeism, the next step is to find out whether the differences will be statistically significant between the UWI and the UI students.

Research Question 3: Will there be statistically significant difference in the causes of absenteeism between UWI 
and UI students?

\section{Insert Table 4 Here}

As shown in table 4, it was found that the UWI and UI students were most significantly different in the school causes $(F(1,998)=244.63, p<.001)$, more significantly different in society causes $(F(1,998)=62.77, p<.001)$, and least significantly different in home causes, $(\mathrm{F}(1,998)=34.40, \mathrm{p}<.001)$; while there was no significant difference in the students-centred reasons for absenteeism. In other words, the students from both institutions have the same personal reasons for absenteeism from lectures while their home, school and society related reasons differ. Of particular interest to the researchers is also to find out whether gender will affect the students' reasons for absenteeism.

Research Question 4: Will gender affect the causes of absenteeism between UWI and UI students?

\section{Insert Table 5 Here}

The findings on table 5 revealed that among the UWI students, males had higher means in home and society causes than their female counterparts, while females had higher means in student-centred and school causes than the males. In other words, the causes of males' absenteeism from lectures are more resident in the home and the society while those of females are more personal and more resident in school, although these differences were not statistically significant.

\section{Insert Table 6 Here}

As shown in table 6 and in figure 2, it was found that among the UI students, there were significant gender differences in the student-centred causes $(\mathrm{t}=5.06, \mathrm{P}<0.05)$ with males having higher means $(\mathrm{M}=30.53)$ than females $(\mathrm{M}=28.52)$ and also in school related causes of absenteeism $(\mathrm{t}=3.83, \mathrm{P}<0.05)$ with females having higher means $(\mathrm{M}=36.18)$ than males $(\mathrm{M}=34.33)$ indicating that males and females have different personal and school related reasons for absenteeism from lectures. However, the differences in home and society causes were not significant although in home causes, males had slightly higher means $(M=19.79)$ than females $(M=19.48)$ while females had slightly higher $(M=15.57)$ means than males $(M=15.37)$ in society causes. These results also indicated that males and females in UI have similar home and society reasons for absenteeism from lectures.

Insert Figure 2 here

\section{Discussion}

The problem of students' absenteeism from lectures is becoming the concern of every member of society because of its grievous consequences on the individual in particular and the society in general. This study investigated the student-centred, home, school and society related causes of absenteeism among the students at The University of the West Indies, Barbados and University of Ibadan, Nigeria.

One of the major findings of this study as seen on table 2 is that there is a problem of absenteeism from lectures among the UWI and UI students indicating its prevalence across the two institutions and that the students skip classes because of school, student-centred, home and society reasons.

This result provides an interesting theoretical link to the nature of learning process which is inherently difficult and mentally tasking. Investigators such as Illeris (2004) and Ormrod, (1995) posit that learning brings together cognitive, emotional, and environmental influences and experiences for acquiring, enhancing or making changes in one's knowledge, skills, values and world views. It is also thought of as the way in which information is absorbed, processed, and retained which require serious attention and good functioning of students' mental capabilities. Since the main purpose of coming for lectures is to learn and acquire knowledge, many students see it as too demanding and stressful when compared with relaxing at home, going to parties and beaches, watching films and other activities which are more attractive and enjoyable. It may not be surprising then to see the students from the two different learning environments skipping lectures because of the nature of learning activities and lack of interest. This finding amplifies Cleary-Holdforth's (2007) earlier assertion that non-attendance at university seems to be an on-going problem that appears to transcend country, university and discipline and also lends credence to the recent finding by Wadesango and Machingambi (2011) that absenteeism is rampant among the students in three South African universities due to reasons including: lack of subject interest, poor teaching strategies by lecturers, unfavourable learning environment, too much socialization and part-time jobs to augment meagre bursaries.

The results on table 3 and figure 1 also show that both UWI and UI students' reasons for being absent from lectures are personal or student-centred, home, school and society related causes. Expectedly, out of the four categories, the sample of this study indicated that the school related reasons such as "poor teaching skills of 
lecturers leading to boring lectures", "lecturers not turning up for scheduled lectures" and "clashes on time table" are mostly responsible for their absenteeism. Student-centred reasons such as "lack of interest in school subjects or courses", "inability of the mental capacity of students to match the course or courses opted for" were also identified as being more responsible for absenteeism followed by home related causes like "working to meet up the daily needs for the family", "poor family relationships" and lastly by society related causes such as "low societal value for education", "transportation problems".

One probable explanation for the most significant outcome of school or academic related reasons is that they are very important and pivotal to students' attendance at lectures. Suffice to say therefore that if the students are interested in the lectures and the parents as well as the society are supportive, students are likely to skip boring lectures and those that are not relevant to their future needs. This finding corroborated the earlier report by Hunter and Tetley (1999) who found that the tertiary education students will not miss lectures that are interesting and those considered important to their degree, those in which there was a lot of material given out, those where they liked the subject content or in which the lecturer was good, while those that they will not attend according to (Gump, 2006; Nicholl \& Timmins, 2005) were perceived as academy-centred such as: failure to connect the content of the lecture to assessment or the 'real world', the availability of lecture material in online forms, unexciting, unchallenging lecturers, timing of lectures and competing assignment commitments.

Another major finding of this study as revealed on tables 3 and 4 is that both the UWI and UI students differ significantly in their reasons for absenteeism from lectures thus: the UI students' reasons for absenteeism are more school and home based than their counterparts in UWI whose reasons for absenteeism are more resident in the society. Interestingly, the almost equal mean scores obtained by both UWI and UI students in student-centred causes show that they have similar student-centred reasons for absenteeism from lectures in spite of the different environments. These findings may be attributed to the fact that these students come from different environments and cultural set up which may probably impact on school causes such as "poor teaching skills of lecturers leading to boring lectures", as well as home causes like; "working to meet up the daily needs for the family" and society related causes such as "low societal value for education", which are liable to environmental influences and can be controlled by external forces like the educational policies, child rearing practices and traditions, country's economy, politics and system of government. Perversely, the finding of this study reveals that the university students from both institutions are similar in their student-centred reasons for absenteeism such as "lack of interest in school subjects or courses". This seemed to be logical because these are internal causes which are personal to the students which transcend cultural barriers and environmental influences, hence the non significant difference in their student-centred reasons for absenteeism.

The last finding of this study as revealed on table 6 is that significant gender differences existed among the UI students in the student-centred causes with males having higher means than females and females having higher means than males in school related causes of absenteeism indicating that males and females have different student-centred and school related reasons for absenteeism from lectures. Thus, the male university students may not likely attend lectures because of personal reasons like: lack of intrinsic motivation and interest in the school and school courses while the females may not attend because of academy - centred reasons like boring, uninteresting, irrelevant and unchallenging lectures delivered in a climate not conducive to learning.

These findings on gender disparity in reasons for absenteeism from lectures among the UWI and UI students also correspond to gender differences in measures of interest in school in terms of participation in academic activities and performance thereby generating results that are quite consistent with the extant literature in this field that girls work harder and attend classes more frequently than boys; boys disregard authority, and that there are differences in students' attitudes to work, maturity and effective learning strategies (Baker \& Jones 1993; Fayombo 2010; Wainer \& Steinberg, 1992). Thus, females excel in their studies and outperformed their male counterparts as found among undergraduate students in a large public university in Turkey, (Dayığlu, and Türüt-Aşik 2004) because of school related or academic reasons like interesting, captivating, motivating lectures facilitated by the females' preferred choice of subjects like language arts and music which are inherently interesting as found in a representative sample of students from United States, Taiwan and Japan (Evans, Schweingruber, \& Stevenson 2002). However, females who have lower self efficacy in computing and marketing than male students as found by Busch (1995) among Norwegian College students as well as other maths-related and traditionally male-dominated subjects such as computer science as reported by Betz and Hackett (1983) and Post-Hammer and Smith, (1985) may likely skip classes. On the other hand, males may likely attend lectures because of their interest and motivation in science, math, and sports and because of more role models to emulate, greater verbal encouragement, and less fear of the machines, (Evans, Schweingruber, \& Stevenson 2002).

Finally, the non significant outcome of gender differences between the UI male and female students' home and 
society reasons for absenteeism from lectures as well as the non significant gender differences in the reasons for absenteeism among the male and female students in UWI as seen in tables 5 and 6 may be attributed to the same cultural setup and environment that both the males and the females have been brought up, hence, the similarities in their reasons for absenteeism.

\section{Conclusion}

This study has shown that the problem of absenteeism is quite prevalent among the university students in Barbados and Nigeria, hence its accentuation around the globe. The problem is caused by the interaction of a multiplicity of factors namely: student-centred, home, school and society related reasons. The student-centred reasons are personal and internal to the students and may not be controlled externally, while the home, school and society related reasons are external to the students and they may be manipulated. It was found that the school factors were primarily responsible for absenteeism among both UWI and UI students, again pointing the accusing fingers at the lecturers as found in many studies that the tertiary education students will not miss lectures that were interesting and those considered important to their degree (Hunter and Tetley 1999), while those that they will not attend according to (Gump, 2006; Nicholl \& Timmins, 2005) were perceived as academy-centred such as: failure to connect the content of the lecture to assessment or the 'real world', the availability of lecture material in online forms, unexciting, unchallenging lecturers. The problem of student absenteeism from lectures cuts across the different levels of education and is also spreading around the globe as evident in this study and if this problem is not addressed, it may have debilitating consequences on the quality of graduates from the universities.

\section{Recommendations/Solutions}

In order to solve the problem of students' absenteeism, all the four facets of the causes must be addressed in order of magnitude thus:

\section{School or Academic Causes}

1) Lecturers' needs should be identified and their skills be enhanced through various training programmes and seminars so as to change their orientation from the traditional lecture method to interactive and innovative lecture method. A step towards this has been taken by The University of the West Indies, Cave Hill Campus, Barbados by encouraging all faculty to undergo the Certificate in University Teaching and Learning (CUTL) training to enhance lecturer's teaching skills and enable them to be more effective teachers.

2) It is imperative that the lecturers try to respond to the problem of students' absenteeism by exploring creative techniques to increase class attendance. One way of achieving this is to let the students realise that their attendances at lectures are important in that they have significant roles to play in the class through class participation in order to achieve the learning objectives. Thus, lecturers should see the students as co-partners in business whose efforts are also necessary for the teaching learning process to be effective.

3) It is also necessary for lecturers to keep the attendance register to be able to monitor students' attendances at lectures. Once in a while, lecturers can deliberately call the names of the absentees to participate in the lectures. This again will create the feelings of being cared for in the students and encourage them to come for lectures especially if the lecturer sends their friends to them that he will like to see them in the classroom.

4) Lecturers should be good models by attending lectures regularly and punctually.

5) Lecturers should be well prepared for the lectures, arrest the attention of the students by presenting a good problem, the use of animation, audio, graphics, thereby stimulating learning and making the learners to be curious and be motivated to learn the subject/skill that the course addresses as suggested by Gagné (1985).

6) Wadesango and Machingambi (2011) in addition, suggested that the implementation of effective and functional student orientation and student support programmes could also be part of the intervention strategies that universities might need to consider among others. Students need regular guidance and counselling services as well as career support so that they may be able to cope with university life and all that goes with it.

7) Hunter and Tetley (1999) concluded that the school or academic information is of tremendous value to educators as it provides direction with regard to what students want from lectures, what excites them and ultimately, what may encourage them to attend. Quinn (2000) and Toohey (1999) also suggested that as part of the solutions, it is imperative that as much as possible, educators endeavour to ensure that their lectures are interesting, relevant, delivered in a positive manner and in an environment that affords respect and equality to all as well as in a climate that is conducive to learning. 


\section{Student-Centred Causes}

1) Students' interests in learning are paramount to their attendances at lectures, they must be self driven as this intrinsic motivation is stronger than the extrinsic motivation from lecturers, parents and the society and therefore yields better result in learning. As the students are being externally motivated and encouraged to attend lectures, they should also be willing to learn as this will make learning meaningful and even facilitate their attendance at lectures

2) There is a popular adage that "you can drag a horse to water but you cannot force it to drink unless it is thirsty". It is when the students are thirsty for knowledge that that they go for lectures. Lecturers open the door, but the students must enter by themselves.

3) Students are "architects of their own fortune", therefore, they should be active learners by participating in the class activities during lectures and the tutorials and they should also be resourceful in order to develop and improve their mental capability as well as complement lecturers' efforts in the class.

4) All these recommendations for solving student-centred causes of absenteeism lend credence to Bulunuz and Jarret (2009) assertion that there is a connection between interest and effort. The more a person is interested in a subject, the more effort he will put into it. He further described an interested person as being engaged, engrossed or entirely taken up by an activity because of its recognized worth. Suffice to say therefore that students' interests will also sustain their lecture attendance.

\section{Home Causes}

1) Parents' efforts are also vital to students' attendance at lectures. They should provide the financial, moral, social and emotional support essential for their wards' regular attendance at school. Parents should not shift the financial responsibilities to the students and should avoid unnecessary demands from them and at the same time, the parents should guide against over pampering the students so that they will have self discipline, respect their lecturers and find it valuable to attend lectures and participate in class activities.

2) Parents should also model punctual and regular attendance at their workplace. Parents who often give flimsy excuses for being absent from work are bad models for the children to emulate.

\section{Society Causes}

1) It is advisable that universities which had been subsidising school fees heavily should take stringent measures to ensure that the students value what they have and come for lectures regularly.

2) All the people in the society, the psychologists, educators, school guidance counsellors, policy makers in the government, religious leaders etc should all come together to combat the problem of students' absenteeism from lectures by advising the students at various levels of education on the importance of attendance at lectures on their academic achievement and their future application skills.

3) It is hoped that these suggestions will make a difference.

This study had uniquely contributed significantly to the body of literature on students' reasons for absenteeism from lectures especially by looking at the different facets of reasons (school, student-centred, home and society) across two public universities; UWI in Barbados (in the Caribbean) and UI in Nigeria (in Africa). Further research can however be carried out to investigate the influence that age groups, course of study, year in the university and mode of study may have on students' reasons for absenteeism from lectures. One of the school related reasons for absenteeism that also needs further investigation is the impact of lecture notes on attendance.

\section{References}

Baker, D. P., \& Jones, D. P. (1993). Creating gender equality: Cross-national gender stratification and mathematical performance. Sociology of Education, 66, 91-103. http://dx.doi.org/10.2307/2112795

Betz, N. E., \& Hackett, G. (1983). The relationship of Mathematics self-efficacy expectations to the selections of science-based college majors. Journal of Vocational Behaviour, 23, 32-345. http://dx.doi.org/10.1016/0001-8791(83)90046-5

Busch, T. (1995). Gender differences in self efficacy and academic performance among students in business administration. Scandanivian Journal of Educational Research, 39, 311-318. [Online] Available: http://www.toh.hist.no/ tor/forskning/se_sje.pdf

Bulunuz, M., Jarrett, O., \& Bulunuz, N. (2009). Middle school students' conceptions on physical properties of air. Journal of Turkish Science Education, 6(1), 37-49. 
Cleary-Holdforth, J. (2007). Student non-attendance in higher education: A phenomenon of student apathy or

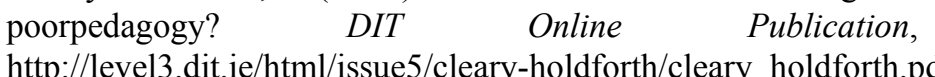

5. [Online]

Available:

Dhaliwal, U. (2003). Absenteeism and under-achievement in final year medical students. The National Medical Journal of India, 16(1), 34-37.

Epstein, J. L., \& Sheldon, S.B. (2002). Present and Accounted For: Improving student attendance through family and community involvement. The Journal of Educational Research, 95, 308-318. http://dx.doi.org/10.1080/00220670209596604

Evans, E. M., Schweingruber, H., \& Stevenson, H. W. (2002). Gender Differences in Interest and Knowledge Acquisition: The United States, Taiwan, and Japan. Sex Roles, 47(3/4), 99-200. http://dx.doi.org/10.1023/A:1021020920715

Eweniyi, G. D. (2002) Curbing examination malpractices among the university students. The efficacy of moral/religious counselling in checking examination malpractices among secondary schools. Journal of Guidance and Counselling, 8(1), 47-60.

Ezema, P. A. (2001). Coping with challenges of realistic assessment in English in higher education In A.U. Akubue, \& D.E. Enyi (Eds.) Crisis and challenges in higher education in developing countries: A book of readings (pp. 382-388), Ibadan; Wisdom

Fayombo, G. A. (2010). Absenteeism from Lectures among Undergraduate Students: Implications for Caribbean Higher Education. In A. Ezenne (Ed.), Higher education in the Caribbean: Research, challenges and prospects (Chapter 14, pp. 509-551). Educational Research Centre, Department of Educational Studies, University of the West Indies, Kingston, Jamaica, West Indies.

Fayombo, G. A. (2010). Gender differences in study habit, interest in schooling and attitude towards substance abuse among secondary school adolescents in Barbados. Caribbean Education Research Journal. 2(1), 87-95.

Fayombo, G. A. (2007). Attitudes of Nigerian lecturers and students towards sexual harassment. Sokoto Educational Review, 9(2), 203-215.

Ford, L. (2006). Oxford University lecture attendance could become legal requirement; guardian.co.uk. [Online] Available: http://www.guardian.co.uk/education/2006/jan/31/students.highereducation (January 31, 2006)

Gagné, R. (1985). The Conditions of Learning and the Theory of Instruction, (4th ed.), New York: Holt, Rinehart and Winston.

Gump, S. E. (2006). Guess who's (not) coming to class: student's attitudes as indicators of attendance. Educational Studies, 32 (1), 39-46. http://dx.doi.org/10.1080/03055690500415936

Hamilton, D., Hinton, L., \& Qian, D. (2008). International students: does attendance as an indicator of involvement correlate with assessment performance? Lifelong Learning: Central Queensland University Press, Rockhampton, paper presented at the 5th Lifelong Learning Conference, Pp.188-194. [Online] Available: http://hdl.cqu.edu.au/10018/13665.

Helenese-Paul, K. (2008). The Library and the Museum: an outline of strategies for enhancing access at The UWI Main Library, St. Augustine," In: New Directions in University Education: Perspectives from the Caribbean. The Learning Resource Centre.

Heriot Watt University. Policy on Student attendance (2007). [Online] Available: http://www.hw.ac.uk/registry/resources/studentattendancepolicy.pdf

Hughes, S. J. (2005). Student attendance during college-based lectures: a pilot study, Nursing Standard, 19(47), 41-49.

Hunter, S., \& Tetley, J. (1999). Lectures. Why don't students attend? Why do students attend? Proceedings of HERDSA Annual International Conference held in Melbourne 12-15 July 1999, Higher Education Research and Development Society of Australia, Milperra, NSW.

Ileris, K. (2004). Transformative Learning in the Perspective of a Comprehensive Learning Theory. Journal of Transformative Education, 2(2), 79-89. http://dx.doi.org/10.1177/1541344603262315

Longhurst, R. J. (1999) Why aren't they here? Student absenteeism in a further education college. Journal of Further and Higher Education, 23(1), 61-80. http://dx.doi.org/10.1080/0309877990230106

Mattick, K., Crocker, G., \& Bligh, J. (2007). Medical student attendance at non-compulsory lectures. Advances in 
Health Sciences Education, 12(2), 201-210. http://dx.doi.org/10.1007/s10459-005-5492-1

McCarey, M., Barr, T., \& Rattray, J. (2006). Predictors of academic performance in a cohort of pre-registration nursing students. Nurse Education Today, 27(4), 357-364. http://dx.doi.org/10.1016/j.nedt.2006.05.017

Moore, S., Armstrong, C., \& Pearson, J. (2008). Lecture absenteeism among students in higher education:a valuable route to understanding student motivation', Journal of Higher Education Policy and Management, 30(1), 15-24. http://dx.doi.org/10.1080/13600800701457848

Nicholl, H., \& Timmins, F. (2005). Programme-related stressors among part-time undergraduate nursing students. Journal of Advanced Nursing, 50(1), 93-100. http://dx.doi.org/10.1111/j.1365-2648.2004.03352.x

Ofovwe, G. E., \& Ofili, A. N. (2007). Knowledge, attitude and practice of school health programme among head teachers of primary schools in Egor local government area of Edo State, Nigeria. Anals of African Medicine, 6(3), 99 -103. http://dx.doi.org/10.4103/1596-3519.55726

Oghuvbu, E. P. (2008). Absebteeism and Lateness Among Secondary School Students in Nigeria:Profiling Causes and Solution. Academic Leadership: Online Journal 3(6). [Online] Available: http://www.academicleadership.org/article/absebteeism-and-lateness-among-secondary-school-students-in nigeriaprofiling-causes-and-solution

Ormrod, J. E. (1995). Human Learning. Englewood Cliffs, NJ: Prentice Hall.

Quinn, F. M. (2000) Principles and Practice of Nurse Education, 4th edn, London: Stanley Thornes.

Sade, R. M., \& Stroud, M. R. (1982). Medical Student Attendance at Lectures: Effect on Medical School Performance. Journal of Medical Education, 3(57), 191-92.

Sharma, M. D., Mendez, A., \& O’Byrne, J. W. (2005). The relationship between attendance in student-centred physics tutorials and performance in university examinations. International Journal of Science Education, 27 (11), 1375-1389. http://dx.doi.org/10.1080/09500690500153931

Toohey, S. (1999) Designing Courses for Higher Education, Buckingham: Open University Press.

The University of Ibadan (UI), Faculty of Education Postgraduate Prospectus, Regulations governing the conduct of examinations (2006). pp 17-18.

The University of the West Indies, Cave Hill, Mona, and St Augustine Campuses (2010/2011). Undergraduate Students' Handbook, p.11. [Online] Available: http://cavehill.uwi.edu/chol/documents/ EXAM_REGULATIONS_EXTRACTS_2011_2012.pdf

Wadesango, N., \& Machingambi, S. (2011). Causes and Structural Effects of Student Absenteeism: A Case Study of Three South African Universities. Journal of Social Science, 26(2), 89-97.

Wainer, H., \& Steinberg, L. S. (1992). Sex Differences in Performance on the Mathematics Section of the Scholastic Aptitude Test: A Bidirectional Validity Study. Harvard Educational Review, 62, 323-336.

Watson E. F., \& Barbado, J. G., (2008). (Eds.) Book Review - New Directions In: Videos in the Classroom: Experiences from a developing country," - New Directions in University Education: Perspectives from the Caribbean. The Learning Resource Centre, The University of the West Indies. ISBN: 978-976-8251-71-0. [Online] Available: http://www.irrodl.org/index.php/irrodl/article/viewFile/544/1032

Yakubu, L.O. (1998). Various tricks adopted by students in perpetuating examination malpractices in tertiary institutions: A case study of Ondo State College of Education, Ikere-Ekiti. MA. Adegboye, 0. Odutoye, \& J.0. Adetunberu (Eds.), Issues on examination maipractices in Nigeria: A book of readings (pp. 62- 73). Ikere-Ekiti: Ondo State College of Education, Nigeria. 
Table 1. Rotated component matrix

\begin{tabular}{|c|c|c|c|c|}
\hline & \multicolumn{4}{|c|}{ Component } \\
\hline & 1 Student & 2 Home & 3 School & 4 Society \\
\hline Item5 student & .826 & .115 & .109 & .233 \\
\hline Item 4 student & .784 & .113 & .135 & .159 \\
\hline Item 3 student & .751 & .223 & .185 & .114 \\
\hline Item 2 student & .633 & -.288 & .210 & .303 \\
\hline Item33 society & -.198 & .207 & .167 & .613 \\
\hline Item1 student & .621 & -.153 & .226 & .388 \\
\hline Item 30 society & .205 & .102 & .335 & .564 \\
\hline Item 8 student & .535 & .203 & .368 & .149 \\
\hline Item 26 school & .107 & .377 & .652 & .294 \\
\hline Item 9 student & .487 & .402 & .128 & -.220 \\
\hline Item 23school & .145 & .163 & .585 & .387 \\
\hline Item 35 society & .315 & .401 & .236 & .431 \\
\hline Item 24school & .214 & .309 & .664 & .444 \\
\hline Item 10 student & .690 & .322 & .283 & 153 \\
\hline Item 25 school & -.126 & .110 & .598 & .210 \\
\hline Item 27 school & -.128 & -.113 & .438 & .314 \\
\hline Item 29society & .116 & .271 & .287 & .429 \\
\hline Item 22 school & -.115 & .145 & .423 & .205 \\
\hline Item 31 society & .244 & .199 & .312 & .444 \\
\hline Item 13 home & .138 & .513 & .118 & .105 \\
\hline Item 15 home & .112 & .653 & .338 & .265 \\
\hline Item 11 home & -.150 & .605 & .268 & .313 \\
\hline Item 28 society & .433 & .217 & -.102 & .525 \\
\hline Item 14 home & .247 & .510 & .416 & -.229 \\
\hline Item 7 student & .485 & .243 & .411 & .302 \\
\hline Item 6 student & .458 & .323 & .387 & .142 \\
\hline Item 18 school & .295 & .376 & .512 & .138 \\
\hline Item 32 society & .283 & .295 & .333 & .501 \\
\hline Item 17 home & .184 & .771 & .397 & .442 \\
\hline Item 16 home & .247 & .647 & .443 & .189 \\
\hline Item 19 school & .119 & .378 & .533 & .334 \\
\hline Item 20 school & .388 & .230 & .494 & .213 \\
\hline Item 21school & .112 & .207 & .434 & .390 \\
\hline Item 12 home & .331 & .486 & -.115 & .386 \\
\hline Item 34 society & .151 & .176 & .265 & .428 \\
\hline
\end{tabular}

Extraction Method: Principal Component Analysis. Rotation Method: Varimax with Kaiser Normalization.A Rotation converged in 9 iterations. 
Table 2. Rate of absenteeism among UWI and UI Students

\begin{tabular}{|l|l|l|l|l|}
\hline \multirow{2}{*}{$\begin{array}{c}\text { No. of times I have missed } \\
\text { classes this semester }\end{array}$} & \multicolumn{2}{|c|}{ UWI Students $(\mathrm{n}=500)$} & UI Students $(\mathrm{n}=500)$ \\
\cline { 2 - 6 } & 10 & 2 & \multicolumn{2}{c|}{ Frequency $\quad(\%)$} \\
\hline Once & 20 & 4 & 15 & 3 \\
\hline Twice & 40 & 8 & 55 & 11 \\
\hline Thrice & 60 & 12 & 45 & 9 \\
\hline Four times & 135 & 27 & 140 & 28 \\
\hline Five times & 130 & 26 & 120 & 24 \\
\hline Six times & 50 & 10 & 60 & 12 \\
\hline Seven times & 55 & 11 & 50 & 10 \\
\hline More than seven times & 500 & 100 & 500 & 100 \\
\hline Total & & & & \\
\hline
\end{tabular}

Table 3. Means Scores, Standard Deviations, Standard Error for the various causes of absenteeism among The UWI ( $\mathrm{n}=500)$ and UI $(\mathrm{n}=500)$ Students

\begin{tabular}{|l|l|l|l|l|l|l|}
\hline Variables & Institution & Min & Maxi & Mean & Std Dev. & Std Error \\
\hline \multirow{3}{*}{ Student-centered causes } & UWI & 12.00 & 48.00 & 29.14 & 5.70 & .255 \\
\cline { 2 - 7 } & UI & 19.00 & 37.00 & 29.37 & 5.93 & .201 \\
\hline \multirow{3}{*}{ Home related causes } & UWI & 8.00 & 30.00 & 17.74 & 5.23 & .235 \\
\cline { 2 - 7 } & UI & 8.00 & 29.00 & 19.61 & 4.80 & 215 \\
\hline \multirow{3}{*}{ School related Causes } & UWI & 12.00 & 48.00 & 30.01 & 5.42 & .242 \\
\cline { 2 - 7 } & UI & 14.00 & 43.00 & 35.40 & 5.43 & .243 \\
\hline \multirow{3}{*}{ Society related Causes } & UWI & 8.00 & 32.00 & 17.60 & 4.08 & .182 \\
\cline { 2 - 7 } & UI & 6.00 & 24.00 & 15.49 & 4.34 & .194 \\
\hline
\end{tabular}

Table 4. Summary of ANOVA Table showing the significant differences in the causes of absenteeism among the UWI and UI students $(\mathrm{n}=1000)$

\begin{tabular}{|c|c|c|c|c|c|c|}
\hline Source & & $\begin{array}{l}\text { Sum of } \\
\text { Squares }\end{array}$ & df & $\begin{array}{c}\text { Mean } \\
\text { Square }\end{array}$ & $\mathrm{F}$ & Sig \\
\hline \multirow{3}{*}{$\begin{array}{l}\text { Student } \\
\text { Causes }\end{array}$} & Between Groups & 13.69 & 1 & 13.69 & .52 & .471 \\
\hline & Within Groups & 26311.30 & 998 & 26.36 & & \\
\hline & Total & 26324.99 & 999 & & & \\
\hline \multirow{3}{*}{$\begin{array}{l}\text { School } \\
\text { Causes }\end{array}$} & Between Groups & 7193.12 & 1 & 7193.12 & 244.63 & $.000 * *$ \\
\hline & Within Groups & 29341.35 & 998 & 29.40 & & \\
\hline & Total & 36534.48 & 999 & & & \\
\hline \multirow{3}{*}{$\begin{array}{l}\text { Society } \\
\text { Causes }\end{array}$} & Between Groups & 1113.03 & 1 & 1113.03 & 62.77 & $.000 * *$ \\
\hline & Within Groups & 17697.13 & 998 & 17.73 & & \\
\hline & Total & 18810.15 & 999 & & & \\
\hline \multirow{3}{*}{$\begin{array}{l}\text { Home } \\
\text { Causes }\end{array}$} & Between Groups & 870.49 & 1 & 870.49 & 34.40 & $.000 * *$ \\
\hline & Within Groups & 25252.89 & 998 & 25.30 & & \\
\hline & Total & 26123.38 & 999 & & & \\
\hline
\end{tabular}

Note: $* * \mathrm{p}<0.01$ 
Table 5. Effect of gender on causes of absenteeism among UWI students (Male, $\mathrm{n}=205$; female, $\mathrm{n}=295 ; \mathrm{df}=498$ )

Note: Not significant $\mathrm{P}>0.05$

\begin{tabular}{|c|c|c|c|c|c|c|}
\hline Variables & Gender & Means & $\begin{array}{l}\text { Std } \\
\text { Dev }\end{array}$ & Std Error & $\mathrm{t}$ & $\mathrm{p}$ \\
\hline \multirow{2}{*}{$\begin{array}{l}\text { Student } \\
\text { Causes }\end{array}$} & Male & 26.71 & 5.49 & .466 & \multirow[b]{2}{*}{1.40} & \multirow[b]{2}{*}{.161} \\
\hline & Female & 28.91 & 5.78 & .304 & & \\
\hline \multirow{2}{*}{$\begin{array}{l}\text { Home } \\
\text { Causes }\end{array}$} & Male & 28.91 & 5.10 & .433 & \multirow[b]{2}{*}{1.31} & \multirow[b]{2}{*}{.190} \\
\hline & Female & 17.55 & 5.29 & .279 & & \\
\hline \multirow{2}{*}{$\begin{array}{l}\text { School } \\
\text { Causes }\end{array}$} & Male & 29.42 & 5.66 & .481 & \multirow[b]{2}{*}{1.58} & \multirow[b]{2}{*}{.113} \\
\hline & Female & 30.27 & 5.30 & .279 & & \\
\hline \multirow{2}{*}{$\begin{array}{l}\text { Society } \\
\text { Causes }\end{array}$} & Male & 17.68 & 4.18 & .355 & \multirow[b]{2}{*}{.34} & \multirow[b]{2}{*}{.735} \\
\hline & Female & 17.55 & 4.02 & .212 & & \\
\hline
\end{tabular}

Table 6. Effect of gender on causes of absenteeism among UI students (Male, $n=211$; female, $n=289 ; d f=498$ )

\begin{tabular}{|c|c|c|c|c|c|c|}
\hline Variables & Gender & Means & $\begin{array}{l}\text { Std } \\
\text { Dev }\end{array}$ & Std Error & $\mathrm{t}$ & $\mathrm{p}$ \\
\hline \multirow{2}{*}{$\begin{array}{l}\text { Student } \\
\text { Causes }\end{array}$} & Male & 30.53 & 4.82 & .332 & \multirow[b]{2}{*}{$5.06^{*}$} & \multirow[b]{2}{*}{.000} \\
\hline & Female & 28.52 & 4.04 & .238 & & \\
\hline \multirow{2}{*}{$\begin{array}{l}\text { Home } \\
\text { Causes }\end{array}$} & Male & 19.79 & 4.41 & .331 & \multirow[b]{2}{*}{.710} & \multirow[b]{2}{*}{.478} \\
\hline & Female & 19.48 & 4.81 & .283 & & \\
\hline \multirow{2}{*}{$\begin{array}{l}\text { School } \\
\text { Causes }\end{array}$} & Male & 34.33 & 6.62 & .456 & \multirow[b]{2}{*}{$3.83 * *$} & \multirow[b]{2}{*}{.000} \\
\hline & Female & 36.18 & 4.20 & .247 & & \\
\hline \multirow{2}{*}{$\begin{array}{l}\text { Society } \\
\text { Causes }\end{array}$} & Male & 15.37 & 4.70 & .323 & \multirow[b]{2}{*}{.521} & \multirow[b]{2}{*}{.603} \\
\hline & Female & 15.37 & 4.07 & .239 & & \\
\hline
\end{tabular}

Note ** Significant $\mathrm{P}<0.05$; Not significant $\mathrm{P}>0.05$

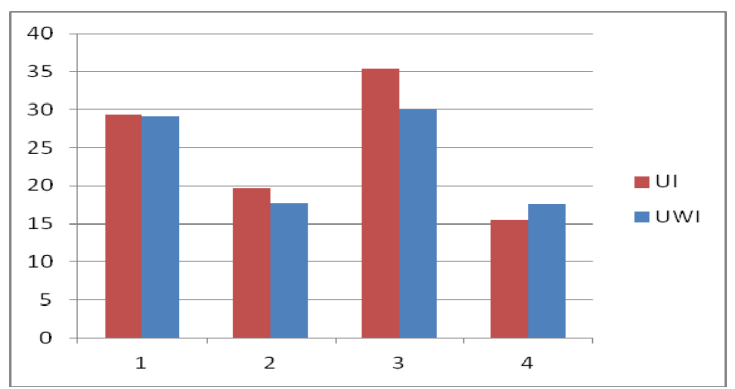

Figure 1. Mean scores showing the school, student, home and society related causes of absenteeism among the UWI and UI students

Note 1: Student-centred causes

Note 2: Home related causes

Note 3: School related causes

Note 4: Society related causes 

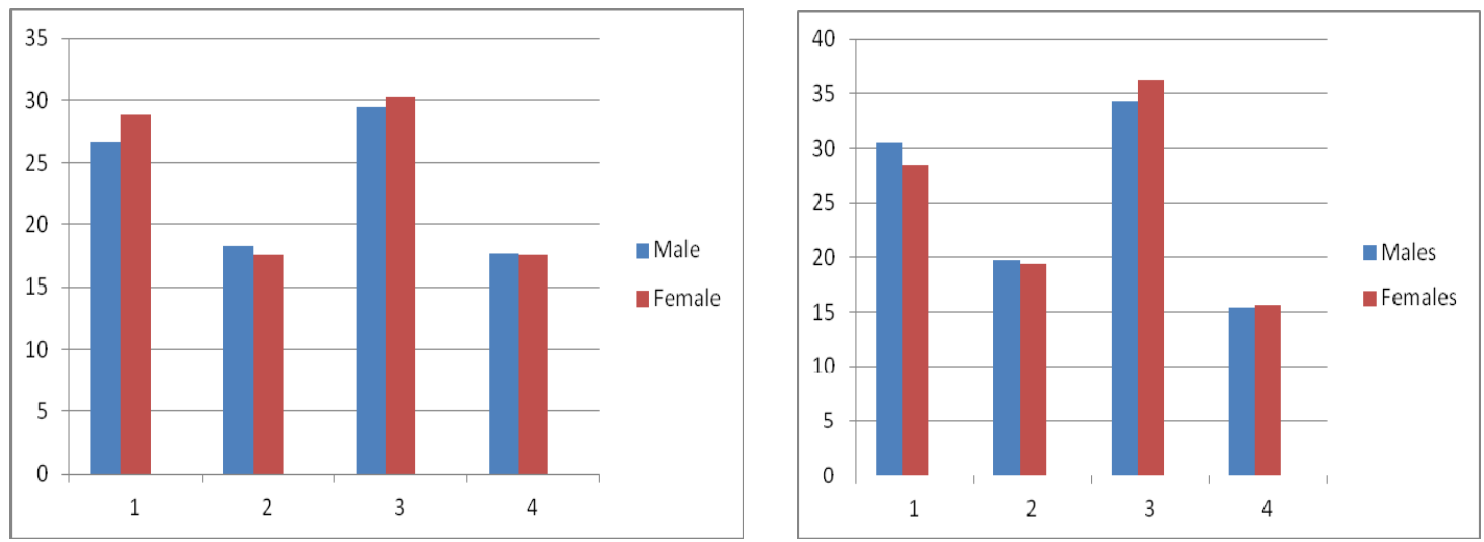

Figure 2. Results of Independent t-test showing gender differences in causes of absenteeism

Note 1: Student-centred causes

Note 2: Home related causes

Note 3: School related causes

Note 4: Society related causes 